\title{
Using LMS Schoology to Improve Learning Outcome of English Teacher Training Participants
}

\author{
Widayanto, widayantoku@gmail.com, Religious Education and Training Center \\ Surabaya
}

\begin{abstract}
This research was based on the teaching and learning process now in the education and training field which most of it still tends to be done conventionally. Learning through E-learning can overcome the constraints of space and time. Widyaiswara (Instructor) and training participants can make the learning process both synchronous (direct), and asynchronous (indirectly) through the virtual world. This study is intended to describe the influence of LMS Schoology in improving the learning outcomes of English Training participants in Religious Education and Training Center (BDK) Surabaya. Formulation of the problem "Is there a significant and positive influence on the use of LMS Schoology on Improving Learning Outcomes of English Teacher Training Participants?" The research method used is pre-experimental one group pretest-postets with regression analysis. Regression analysis is used to find out how much influence the independent variable has on the increase in the dependent variable. The results showed that after teaching and learning process was carried out with the LMS Schoology application media there is a significant and positive influence on the use of LMS Schoology to increase the learning outcomes of English Teacher Training participants and the amount of the influence of the LMS Schoology usage variable on the increase participant learning outcomes is $77.4 \%$. That is, the effect of LMS Schoology on the learning outcomes of training participants is $77.4 \%$. The findings may encourage instructors to use LMS Schoology in order to increase the learning outcomes of Teacher Training participants.
\end{abstract}

Keywords: E-learning, LMS Schoology, learning outcomes

\section{A. INTRODUCTION}

The development of information technology which is rapidly increased in the current era of globalization and its impact on education cannot be avoided anymore. Global demands require education to always and constantly adapt technological developments as efforts to improve the quality of education, the adjustment of its use for education, especially in the teaching and learning process. Information technology is the development of information systems by combining computer technology with telecommunications (Baharudin 2013). In the teaching and learning process in an educational environment, information technology as a media is one of the factors that influence the achievement of learning objectives. Widyaiswara, training participants, environment, methods are also very influential factors in it. Information and communication technology has become an important element in education as a learning media in the form of electronic learning. 
Electronic learning system (Electronic learning abbreviated as E-learning) is a new way of teaching and learning. E-learning is the basis and logical consequence of the development of information and communication technology. With E-learning, learning participants (learners or students) do not need to sit nicely in the classroom to listen to every word of a teacher directly. E-learning can also shorten the target learning time schedule, and of course save costs that must be incurred by a study program or educational program. E-learning has shortened learning time and made study costs more economical. E-learning facilitates the interaction between training participants and materials, training participants and lecturers and fellow training participants. Training participants can share information with each other and can access learning materials at any time and repeatedly, with such conditions training participants can strengthen their mastery of learning materials.

In E-learning, the attendance factor of the lecturer / instructor or teacher automatically decreases or doesn't even exist. This is because those who take on the role of instructors are computers and electronic guides designed by contents writers, Elearning designers and computer programmers, through the given web platform.

The use of information technology is currently able to improve integrity and quality in the teaching and learning process, because the use of the technology can increase access, accelerate the learning process, and reduce administration. The learning process in education is mostly carried out by conventional methods. The conventional method consists of several methods including lectures as the main method, plus questions and answers, discussion, and recitation/assignments.

Currently, there are several courses offered online (E-Learning), such as edmodo, moodle, and schoology, which are currently popular. Schoology is a social learning management system (LMS) that offers free and easy to use learning (Putri, Jampel, and Suartama 2014). Moodle is the most widely used LMS for creating Elearning websites, however Schoology combines social networking features with an LMS so that it can interact socially as well as learn. LMS Schoology is very complete with various learning tools as it is done in the real world, starting from checking attendance, tests, quizzes, to collecting student assignments (Amiroh 2013). LMS Schoology allows the collaboration of various individual data, groups, and class discussions so that LMS Schoology is very suitable to be used as a supporting learning media using E-learning.

LMS Schoology is one of several Learning Management Systems (LMS) that provides facilities for lecturers and students to interact with each other, exchange information online. With the LMS Schoology, it is expected that training participants can download subject matter, presentation slides, video tutorials, games, do quizzes, exams, discussions, and collect assignments given by the teacher. LMS Schoology can also be operated via a computer or smartphone.

The magnitude of the influence of using LMS Schoology on learning outcomes was carried out by (Murni 2016), with a study entitled "The Effect of Schoology-Based E-learning on Improving Student Learning Outcomes in Network Hardware Materials Class X TKJ 2 at SMK Negeri 3 Buduran Sidoarjo". Their findings say that there is a significant positive effect between Schoology-based E-learning on student learning outcomes.

The influence of LMS Schoology on learning outcomes is also in a study entitled "The Effect of Using E-Learning with Schoology on Student Learning Outcomes" by (Purwaningsih, Rosidin, and Wahyudi 2017). By using the quasi experimental design method with a non-equivalent type of control group design, which

183 | IJET| Volume. 9, Issue 2. December 2020 Copyright 2020 Widayanto is licensed under Creative Commons Atrribution- ShareAlike 4.0 International License. 
comes to the conclusion that: Learning using E-learning with Schoology makes students more motivated in learning activities, as evidenced by the N-gain test result of 0.70 which states the effect use of E-learning with Schoology on student learning outcomes. Then through the CRI method it is known that students' conceptual understanding is mostly distributed at the level of understanding the correct concept (understanding the concept) of $71.40 \%$; while the rest of the level of understanding the concept is weak $7.05 \%$; lucky $6.73 \%$; and misconceptions $14.82 \%$.

Students who are able to understand the concept correctly are $71.40 \%$. Students are able to understand the concept of momentum as a vector which is closely related to impulses and also the law of conservation of momentum. Meanwhile, the psychomotor skills of students experienced an increase from the average result of the description questions of 15.00 to 84.38 with an average $\mathrm{N}$-gain value of 0.82 (high category) and practicum performance of 83.85 with good predicate, students showed good performance and showed improvement in general.

The present study also carried out by (Aljaser 2019; Fadel 2016; Chou and Liu 2005; Harrington and Aloni 2013) in terms of the effectiveness of E-learning environment in developing academic achievement. It's also consistent with (Wu, $\mathrm{Yu}$, and Wang 2018) emphasizing that E-learning environment helps understand complicated subjects using pictures and charts.

(Aljaser 2019) conducted a quasi-experimental approach research entitled The Effectiveness of E-Learning Environment in Developing Academic Achievement and the Attitude to Learn English among Primary Students. His first research question: What is the Effectiveness of E-Learning Environment in Developing the 5th Grade Student Achievement in English Language? Came to the conclusion that there were statistically significant differences between the mean scores of the students of the experimental group (taught through E-learning environment) and those of the control group (taught by the traditional method) in the post achievement test.

The result of his research showed that there a statistically significant differences between the average scores of students in the control and the experimental groups in the post application of the achievement test at the level of 0.01 , in favor of the students of the experimental group. It means that the level of student achievement in the experimental taught through the E-learning environment is higher than the level of student achievement in the control group taught through the traditional method, The effect size of the independent variable (E-learning environment) on the dependent variable (academic achievement) is significant, indicating the effectiveness of Elearning environment in the development of academic achievement among fifth grade students.

While existing studies have clearly established the indication of the effectiveness of E-learning environment in the improvement of academic achievement among students, they have not addresses to the improvement of learning outcome among the teacher training participants. The present research tries to clarify the effect of E-learning media LMS Schoology on improving the learning outcomes of MA English Teacher Training Participants at Religious Education and Training Center Surabaya.

Madrasah Aliyah (Senior High School) Teacher Trainin is a training to strengthen English Teacher competence. Based on the curriculum and syllabus of the Religious Education and Training Center for Technical Education and Personnel (2018), the Competence Standards for the Madrasah Aliyah (Senior High School) Teacher Training are that Training Participants are able to demonstrate behavior 
according to facts, concepts, procedures, and metacognitive Madrasah Aliyah English Teacher in everyday life. Meanwhile, Basic Attitude Competencies: Religious Attitudes, appreciating and practicing the religion they adhere to, and Social Attitudes, carrying out integrity, professional behavior, innovation, responsibility, and exemplary in training activities. Knowledge Competency: applying social functions, text structure, and language elements of simple spoken and written text in the form of interpersonal, transactional, and functional, and Skills Competency: compile simple interpersonal, transactional, and functional oral and written texts by paying attention to social functions, text structure and linguistic elements which are correct according to the context.

In conventional learning, training participants listen more to the instructor who sits or stands in front of the class explains the material, and carry out assignments if the instructor provides training questions or quizzes to the training participants. After the lecturer gave an explanation of the training material, followed by a question and answer session and discussion then the participants were asked to present the results of the discussion. The lecture method is the delivery of lessons carried out by the instructor with direct oral explanation or explanation in front of students (Abuddin 2011). The lecture begins by explaining the goals to be achieved, revealing the outline to be discussed, and connecting the material to be presented with the material that has been presented. Lecture as a teaching method, namely information and oral explanation by the instructor for class improvement. During the lecture, the instructor can use assistive tools such as pictures and power point slides so that the description becomes clearer. The learning resources used during the teaching and learning process refer to the modules owned by the instructor, so the learning process tends to be boring.

The use of computers in the E-learning as a media of teaching and learning process is needed. Information and communication technology has three important roles in learning; teaching materials, learning medias and learning tools. The learning module is one of the teaching materials used by training participants in the learning process. Learning modules or Module Complementary Materials (MPM) consist of learning materials, methods and evaluations to help training participants achieve the expected competencies. In addition to the learning module or MPM, there are also presentation slides, quizzes, video tutorials and games that can be delivered by Elearning, so that training participants don't feel bored during the teaching and learning process. One of the uses of computers in the learning process is used as a means of Elearning.

E-learning is a way of learning that utilizes electronic media as a tool in the process of teaching and learning activities to improve the learning outcomes of training participants. E-learning can help Widyaiswara in teaching and learning activities, because E-learning can be used at any time even though the learning time is over (Arief, 2011). E-learning can be used without having to meet face to face between lecturers and training participants. So if during the learning process there is a problem, for example the instructor cannot attend because there are other activities, there are meetings/outside services, the training participants can still carry out the learning process. Another example is the extraordinary situation that has occurred recently, where training is conducted online due to the Covid-19 outbreak. This happened at the Class of MA English Teacher Training which initially took place face-to-face, but due to the Covid-19 outbreak, after running for 3 days the training was continued online. Lecturers work from home while training participants can do all their activities from their homes or offices.

185 | IJET| Volume. 9, Issue 2. December 2020 Copyright 2020 Widayanto is licensed under Creative Commons Atrribution- ShareAlike 4.0 International License. 
E-Learning as a web application in the field of learning utilizes the internet (Anwar 2008). E-Learning is very flexible in its management, although it is limited by distance and internet network capabilities. Even so, electronic media with various features makes the learning process more dynamic and fun, and makes it easier for instructors to overcome the difficulties of students to understand concrete and abstract concepts.

E-learning can be classified into three types, namely: (1) Adjunct which is traditional learning with a delivery system that occurs online as enrichment, (2) Mixed / blended, in which the face-to-face learning process and online learning are one unit intact, and (3) Full online, where all interactions in learning and delivery of learning materials occur online. In this study, a mixed / blended model was used, in which the learning process took place face-to-face between lecturers and training participants for 3 days and continued online.

Learning outcomes are an important part of learning. (Sudjana 2009) defines student learning outcomes as a change in behavior as a result of learning in a broader sense covering the cognitive, affective, and psychomotor dimensions. Learning outcomes are the level of mastery achieved by students in following the learning program, in accordance with the objectives set. (Dimyati and Mudjiono 2006), state that what is meant by learning outcomes is a process to see the extent to which students can master learning after participating in the teaching and learning process, or the success achieved by a student after participating in learning activities marked with numbers, letters or certain symbols agreed upon by the education providers.

The learning outcomes that will be examined in this study include aspects of participant knowledge about the development of MA English Teacher professions as evidenced by the results of training participants taking tests using the online LMS Schoology. According to (Anwar 2008), many factors influence learning success in training, including participant characteristics, learning materials, training methods and techniques. In this training, these factors must be fully concerned so that they can be managed as well as possible in order to obtain good education and training learning outcomes.

Based on the description above, the researcher conducted a study which focused on the effect of E-learning media LMS Schoology on improving the learning outcomes of MA English Teacher Training Participants at Religious Education and Training Center Surabaya. The formulation of the problem in this study is: Is there any significant and positive influence on the use of LMS Schoology towards the improvement of learning outcomes of MA English Teacher Training participants? The purpose of this study was to describe the effect of LMS Schoology on the improvement of learning outcomes of MA English Teacher Training participants. The benefit of this research results for Widyaiswara is that LMS Schoology can be used as an alternative learning media in his class and considerations for the Head of the Education and Training Center to make policies in determining the use of educational learning infrastructure.

\section{B. METHOD}

This research was conducted using pre-experimental research method one group pretest-posttest with regression analysis. The pre-experimental group pretest-posttest design was used to determine the level of ability of the training participants before treatment and after treatment. Regression analysis is used to find out how much influence the independent variable has on the increase in the dependent variable.

186 | IJET| Volume. 9, Issue 2. December 2020

Copyright 2020 Widayanto is licensed under Creative Commons Atrribution- ShareAlike 4.0 International License. 
The research design is the steps or design of how a study will be carried out (Kadri 2017). The design carried out in this study was to group the training participants into one group, then the group under study was treated by giving treatment. Before being given treatment by researchers, training participants first did a pretest. Pretest is used to determine the level of ability of training participants before the treatment is carried out. After the researcher gave the treatment, the researcher gave the posttest.

The purpose of the posttest is to determine the level of ability of the training participants after being given treatment. Treatment is carried out by providing training participants with E-learning media with LMS Schoology. To find out the extent of the learning outcomes of the training participants, the pre-experimental one group pretestposttest research design was used. More details regarding the pre-experimental one group pretest-posttest research design will be described in figure 1 .

\begin{tabular}{ccc}
\hline Pretest & Treatment & Posttest \\
\hline $\mathrm{O} 1$ & $\mathrm{X}$ & $\mathrm{O} 2$
\end{tabular}

Figure 1. Pre-experimental One Group Pretest-Posttest Design

Note:

$\mathrm{O} 1=$ Score before being given treatment (Pretest)

$\mathrm{X}=$ Treatment

$\mathrm{O} 2=$ Score after treatment (Posttest)

Hypothesis $0\left(H_{0}\right)$ in this study is: there is no significant and positive effect of using LMS Schoology toward the increasing of learning outcome of MA English Teacher Training Participants in the Religious Education and Training Center Surabaya. Whereas Hypothesis $1\left(H_{1}\right)$ is: there is significant and positive effect of using LMS Schoology towards the increasing of learning outcome of MA English Teacher Training Participants in the Religious Education and Training Center Surabaya.

The instruments used were online tests and questionnaires. The test instrument is in the form of multiple choice test questions with 4 choices of 30 random items with the aim of each participant getting a different question.

The second is the questionnaire. Researcher use five alternative answers, namely "Strongly Agree (SA)", "Agree (A)", "Doubtful (D)", "Disagree (DA)", and "Strongly Disagree (SD)".

Table 1. Scoring

\begin{tabular}{lccccc} 
& SA & A & D & DA & SDA \\
\hline FAV & 5 & 4 & 3 & 2 & 1 \\
UF & 1 & 2 & 3 & 4 & 5
\end{tabular}

For scoring on the questionnaire the total score of the questionnaire for respondents related to the E-learning learning process with LMS Schoology uses 2 types, namely: favorable and unfavorable. Favorable shows that there is a response in 
the learning process. Meanwhile, Unfavorable shows that there is no response in the learning process.

In Favorable scoring type, they are "Strongly Agree (SA) score 5", "Agree (A) score 4", "Doubtful (D) score 3", "Disagree (DA) score 2", "Strongly Disagree ( SDA) score 1". Then the unfavorable scoring type is "Strongly Agree (SDA) score 1", "Agree

a. $\quad$ score 2", "Doubtful (D) score 3", "Disagree (DS) score 4", "Strongly Disagree (SDS) score 5".

To find out which instruments are used properly or not, validation will be performed. Validation is used to validate the Teaching Program Outline (GBPP), Learning Event Unit (SAP) and learning content that will be uploaded into LMS Schoology.

Table 2. Percentage of Content Validation Assessment Criteria

\begin{tabular}{cc}
\hline Score Mean & Criteria \\
\hline $0 \%-20 \%$ & Infeasible \\
$21 \%-40 \%$ & Less Feasible \\
$41 \%-60 \%$ & Quite Feasible \\
$61 \%-80 \%$ & Feasible \\
$81 \%-100 \%$ & Strong Feasible \\
\hline
\end{tabular}

The validation percentage is calculated using the formula:

$$
\mathrm{P}=\frac{x}{x i} \mathrm{X} 100 \%
$$

Note:

$\mathrm{P}=$ percentage of each criterion

$x=$ Score of each criterion

$x i=$ Maximum score for each criterion

Based on the percentage of validation criteria can be said to be valid if the average percentage results obtained reached the percentage $\geq 61 \%$ with the criteria "Feasible" and the average percentage results obtained reached a percentage of $\geq 81 \%$ with the criteria "Strong Feasible".

\section{RESULT AND DISCUSSION}

In this study, the validation test is said to be valid and can be used if the value given by the validator has reached the valid category. There are two validators in this study. They are 2 lecturers from Religious Education and Training Center (BDK) Bandung and Semarang. Validation of learning material content consists of 1) explaining the learning objectives. 2) conformity to the training syllabus. 3) provide an orientation towards theory, theoretical reasoning, and ways of applying theory in practice. 4) there is training on the use of theory. 5) shows other sources of information. Learning materials are in the form of MPM (Module Complementary Material) in PDF

188 | IJET| Volume. 9, Issue 2. December 2020 Copyright 2020 Widayanto is licensed under Creative Commons Atrribution- ShareAlike 4.0 International License. 
format. The results of the validation of the feasibility of learning material content, which amount to 5 aspects, can be seen in table 3 .

Table 3. The Feasibility Validation Results of Learning Material Content

\begin{tabular}{llcc}
\hline No & \multicolumn{1}{c}{ Aspect } & Validator 1 & Validator 2 \\
\hline 1 & explaining the learning objectives & 5 & 5 \\
2 & conformity to the training syllabus & 5 & 5 \\
3 & $\begin{array}{l}\text { provide an orientation towards } \\
\text { theory, theoretical reasoning, and }\end{array}$ & 4 & 3 \\
& $\begin{array}{l}\text { ways of applying theory in practice } \\
4\end{array}$ & & \\
5 & there is training on the use of theory & 5 & 5 \\
\hline
\end{tabular}

The appropriateness of the learning material content for the training course by the validator 1 , there are 3 aspects with a value of 5,1 aspect with a value of 4, and 1 aspect with a value of 3 so that the total score is $(3 \times 5)+(2 \times 4)=23$. The results of validation of Validator 1 are:

$\mathrm{V} 1=\frac{\text { Total Score }}{\text { Maximum Soore }} \mathrm{X} 100 \%$

$\mathrm{V} 1=\frac{23}{25} \mathrm{X} 100 \%=92 \%$

Validator 2, there are 3 aspects with a value of 5, 2 aspects with a value of 3 so that the total score is $(3 \times 5)+(2 \times 3)=21$. The results of validation of Validator 2 are:

$\mathrm{V} 1=\frac{\text { Total Score }}{\text { Maximum Score }} \mathrm{X} 100 \%$

$\mathrm{V} 1=\frac{21}{25} \mathrm{X} 100 \%=84 \%$

The average validation results of the learning material content feasibility are obtained on average $\frac{92+84}{2}=88 \%$. The calculation results of the content validation of learning materials based on the aspects assessed are categorized as "Strong Feasible" to be used with a result of $88 \%$.

The results of the GBPP-SAP feasibility validation which consist of the following aspects: 1) GBPP-SAP identity. 2) the name of the training and training course. 3) time allocation. 4) brief description. 5) general and specific goal of the course. 6) topic and sub-topic of the subject. 7) learning activities. 8) method. 9) media. 10) evaluation. 11) references. and 12) date and name of Widyaiswara.

GBPP-SAP MA English Teacher training course in the form of an ms-word file uploaded to LMS Schoology. The results of the validation of the feasibility of GBPPSAP consists of 12 aspects, can be seen in table 4 .

Table 4. GBPP-SAP Feasibility Validation Results 


\begin{tabular}{llcc}
\hline No & \multicolumn{1}{c}{ Aspect } & Validator 1 & Validator 2 \\
\hline 1 & GBPP-SAP identity & 5 & 5 \\
2 & the name of the training and training course & 5 & 5 \\
3 & time allocation & 5 & 3 \\
4 & brief description & 4 & 4 \\
5 & general and specific goal of the course & 5 & 5 \\
6 & topic and sub-topic of the subject & 5 & 5 \\
7 & learning activities & 5 & 5 \\
8 & Method & 4 & 4 \\
9 & Media & 3 & 5 \\
10 & evaluation & 4 & 4 \\
11 & references & 5 & 4 \\
12 & date and name of Widyaiswara & 5 & 5 \\
\hline
\end{tabular}

The average results of the validation of the GBPP-SAP MA English Teacher Training are obtained on average $\frac{91.7+90}{2}=90.83 \%$. The results of the calculation of the validation of GBPP-SAP based on 12 aspects were categorized as "Strong Feasible" to be used with the result of $90.83 \%$.

The results of the feasibility validation of multiple choice questions consist of the following aspects: 1) questions must match to the indicators. 2) the choice of answers must be homogeneous and logical in terms of material. 3) each question must have one correct or most correct answer. 4) the main question must be formulated clearly and firmly. 5) the formulation of the main questions and the choice of answers must be statements that are needed only. 6) the question does not give clues to the correct answer. 7) the questions should not contain a double negative statement. 8) the length of the formulation of the answer choices must be relatively the same. 9) the answer choices must not contain a statement: all of the above answer choices are correct or all the answer choices above are wrong. 10) The answer choices in the form of numbers or times must be arranged according to the order of the number value or chronological value of the time. 11) pictures, graphs, tables, diagrams and the like stated in the questions must be clear and functional. 12) item questions do not depend on the answer to the previous item. 13) each item must use the language according to the rules of Indonesian. 14) do not use the language applicable locally (certain region) if the question will be used for several regions or nationally. And 15) the choice of answers does not repeat words or phrases that are not a unitary meaning, the word knows the phrase is written on the main question.

There are 30 multiple choice questions for the MA English Teacher Training, which are uploaded to the LMS Schoology. The results of the validation of the feasibility of multiple choice questions in the material, construction, and language aspects can be seen in table 5 .

Table 5. Results of the Feasibility Validation for Multiple Choice Questions 


\begin{tabular}{|c|c|c|c|}
\hline No & Aspect & Val.1 & Val. 2 \\
\hline 1 & questions must match to the indicators & 5 & 5 \\
\hline 2 & $\begin{array}{l}\text { the choice of answers must be homogeneous and logical in } \\
\text { terms of material }\end{array}$ & 5 & 4 \\
\hline 3 & each question must have one correct or most correct answer & 5 & 5 \\
\hline 4 & the main question must be formulated clearly and firmly & 3 & 3 \\
\hline 5 & $\begin{array}{l}\text { the formulation of the main questions and the choice of } \\
\text { answers must be statements that are needed only }\end{array}$ & 4 & 4 \\
\hline 6 & the question does not give clues to the correct answer & 5 & 5 \\
\hline 7 & the questions should not contain a double negative statement & 5 & 5 \\
\hline 8 & $\begin{array}{l}\text { the length of the formulation of the answer choices must be } \\
\text { relatively the same }\end{array}$ & 3 & 4 \\
\hline 9 & $\begin{array}{l}\text { the answer choices must not contain a statement: all of the } \\
\text { above answer choices are correct or all the answer choices } \\
\text { above are wrong }\end{array}$ & 3 & 5 \\
\hline 10 & $\begin{array}{l}\text { The answer choices in the form of numbers or times must be } \\
\text { arranged according to the order of the number value or } \\
\text { chronological value of the time }\end{array}$ & 5 & 5 \\
\hline 11 & $\begin{array}{l}\text { pictures, graphs, tables, diagrams and the like stated in the } \\
\text { questions must be clear and functional }\end{array}$ & 5 & 5 \\
\hline 12 & $\begin{array}{l}\text { item questions do not depend on the answer to the previous } \\
\text { item }\end{array}$ & 4 & 4 \\
\hline 13 & $\begin{array}{l}\text { each item must use the language according to the rules of } \\
\text { Indonesian }\end{array}$ & 3 & 3 \\
\hline 14 & $\begin{array}{l}\text { do not use the language applicable locally (certain region) if } \\
\text { the question will be used for several regions or nationally }\end{array}$ & 4 & 4 \\
\hline 15 & $\begin{array}{l}\text { the choice of answers does not repeat words or phrases that } \\
\text { are not a unitary meaning, the word knows the phrase is } \\
\text { written on the main question }\end{array}$ & 5 & 4 \\
\hline
\end{tabular}

The validation feasibility results on of MA English teacher training multiple choice questions were obtained on average $\frac{88+86.7}{2}=87.35 \%$. The calculation results of the feasibility validation of multiple choice questions based on 15 aspects were considered to be categorized as "Strong Feasible" to be used with a result of $87.35 \%$.

The combined results of calculating the validation of learning material content, GBPP-SAP and multiple choice items as a whole are very feasible. The combined results of the calculations are shown in table 6.

Table 6. Combined Results of Validation Calculations 


\begin{tabular}{lcccc}
\hline \multicolumn{1}{c}{$\begin{array}{c}\text { Validated } \\
\text { Material }\end{array}$} & $\begin{array}{c}\text { Validator } \\
\mathbf{1}\end{array}$ & $\begin{array}{c}\text { Validator } \\
\text { Average }\end{array}$ & $\begin{array}{c}\text { Feasibility } \\
\text { Criteria }\end{array}$ \\
\hline $\begin{array}{l}\text { Learning } \\
\text { Material }\end{array}$ & $92 \%$ & $84 \%$ & $88 \%$ & Strong Feasible \\
Content & & & & \\
$\begin{array}{l}\text { GBPP-SAP } \\
\text { Multiple }\end{array}$ & $91.7 \%$ & $90 \%$ & $90.83 \%$ & Strong Feasible \\
$\begin{array}{l}\text { Choice } \\
\text { Questions }\end{array}$ & $88 \%$ & $86.7 \%$ & $87.35 \%$ & Strong Feasible \\
\hline
\end{tabular}

For learning outcomes, the normality test of the pretest and posttest scores was carried out using Kolmogorov Smirnov. The results of the pretest and posttest data normality test can be seen in table 7 below.

Table 7. Normality Test

\begin{tabular}{|l|r|r|r|r|r|r|}
\hline & \multicolumn{3}{|c|}{ Kolmogorov-Smirnov } & \multicolumn{3}{c|}{ Shapiro-Wilk } \\
\cline { 2 - 7 } & Statistic & \multicolumn{1}{|c|}{ df } & \multicolumn{1}{c|}{ Sig } & Statistic & \multicolumn{1}{c|}{ df } & \multicolumn{1}{c|}{ Sig, } \\
\hline posttest &, 213 & 35 &, 000 &, 879 & 35 &, 001 \\
preetest &, 141 & 35 & 0,045 &, 968 & 35 &, 291 \\
\hline
\end{tabular}

Data source: Processed output of SPSS 21 (SPSS Indonesia, 2020), if the significance is below 0.05 it means that there is a significant difference, and if the significance is above 0.05 then there is no significant difference. The application of the Kolmogorov Smirnov test is that if the significance is below 0.05 , it means that the data to be tested has a significant difference. From the results in Table 7, the pretest sig. 0.045 and the posttest value is sig. 0.000 . The pretest and posttest values below 0.05 means that the data to be tested has a significant difference.

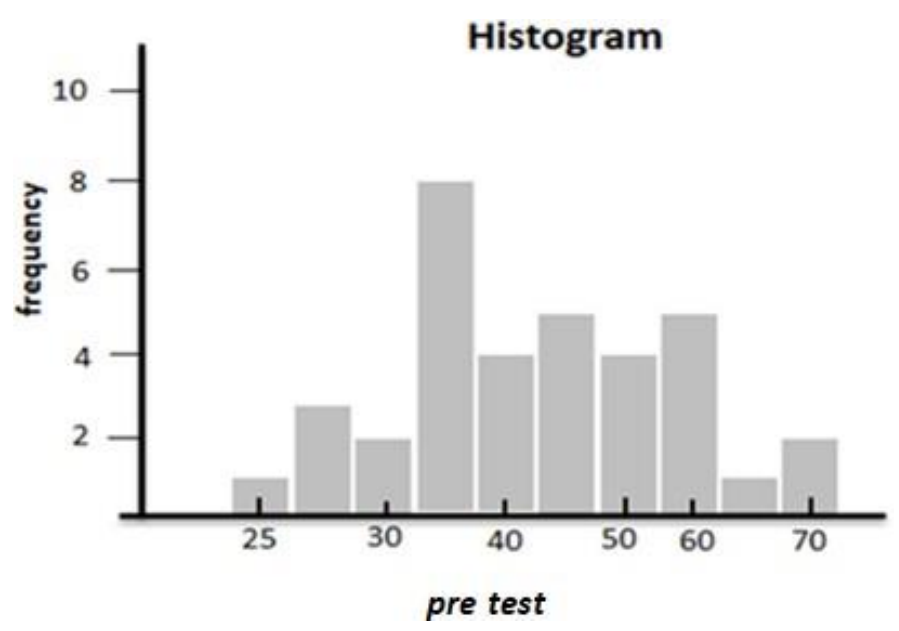

Figure 2. the results of the pre test analysis 
Figure 2 shows the results of the pre-test analysis in the MA English Teacher Training class which consists of 35 training participants. From the learning outcome, the results obtained in detail, the lowest score is 25 and the highest score is 70 .

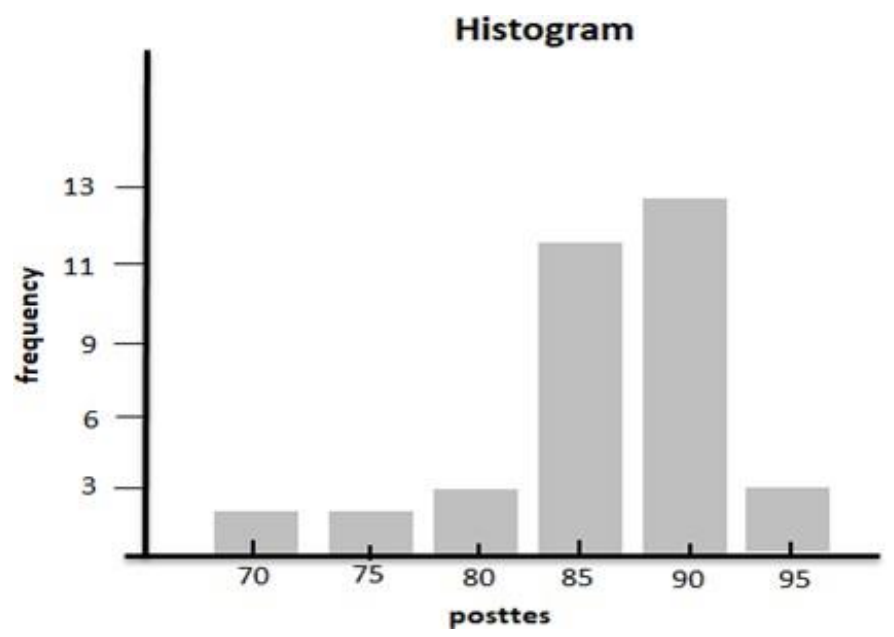

Figure 3. the results of the post test analysis

Figure 3 shows the results of the post-test analysis in the MA English Teacher Training class which consists of 35 training participants. From the learning outcome, the results obtained in detail, the lowest score is 70 and the highest score is 95 .

Table 8. Results of Correlation Test Between the LMS Schoology variable $(\mathrm{X})$ and the learning outcome variable $(\mathrm{Y})$

\section{Correlations}

\begin{tabular}{|ll|l|l|}
\hline & & X & Y \\
\hline X & Pearson Correlation & 1 &, $877^{* \star}$ \\
& Sig. (2-tailed) & &, 000 \\
N & 35 & 35 \\
& Pearson Correlation &, $877^{* \star}$ & 1 \\
Y Sig. (2-tailed) &, 000 & \\
& N & 35 & 35 \\
\hline
\end{tabular}

**. Correlation is significant at the 0.01 level (2-tailed). Data source: SPSS 21 output that was processed in 2020. Table 8 shows that the correlation coefficient (R) test between the LMS Schoology variable (X) and the learning outcome variable (Y) was obtained at $87.7 \%$. This shows that there is a strong relationship between the two variables, because $87.7 \%$ are in the condition $0.75<\mathrm{r}<0.90$ (strong correlation). This means that there is a strong influence between the use of LMS Schoology on improving the learning outcomes of training participants.

Table 9. Determination Test Results Between the LMS

Schoology variable $(\mathrm{X})$ and the learning outcome variable $(\mathrm{Y})$ 


Model Summaryb
\begin{tabular}{|c|r|r|r|r|r|}
\hline Model & $\mathrm{R}$ & $\begin{array}{c}\mathrm{R} \\
\text { Square }\end{array}$ & $\begin{array}{c}\text { Adjusted R } \\
\text { Square }\end{array}$ & $\begin{array}{c}\text { Std. Error 0f } \\
\text { the Estimate }\end{array}$ & $\begin{array}{c}\text { Durbin- } \\
\text { Watson }\end{array}$ \\
\hline 1 &, $877^{a}$ &, 774 &, 770 & 4,335 & 2,356 \\
\hline
\end{tabular}

Data source: SPSS 21 output processed in 2020. Table 9 explains the magnitude of the correlation value (R). When viewed from the R-Square value which is $77.4 \%$ and explained the percentage of influence of the independent variables on the dependent variable called the coefficient of determination which is a quadraction of $\mathrm{R}$. That is, the effect of LMS Schoology on the learning outcomes of training participants is $77.4 \%$ while the remaining $22.6 \%(100 \%-77.4 \%)$ is influenced by other variables that are not in the linear regression model.

Based on the results of the statistical test obtained, Hypothesis $0\left(H_{0}\right)$ in this study is: there is no significant and positive effect of using LMS Schoology toward the increasing of learning outcome of MA English Teacher Training Participants in the Religious Education and Training Center Surabaya is rejected. The consequence is Hypothesis $1\left(H_{1}\right)$ is: there is significant and positive effect of using LMS Schoology towards the increasing of learning outcome of MA English Teacher Training Participants in the Religious Education and Training Center Surabaya is accepted. That's why, the use of LMS Schoology has significant and positive effect on the improvement of learning outcomes of MA English Teacher Training participants. The use LMS Schoology that increased the learning outcomes of Teacher Training participants accords with the findings of studies done by (Mahmud 2019; Purwaningsih, Rosidin, and Wahyudi 2017; Aljaser 2019; Fadel 2016; Chou and Liu 2005; Harrington and Aloni 2013; $\mathrm{Wu}, \mathrm{Yu}$, and Wang 2018).

\section{CONCLUSION}

There is a significant and positive influence on the use of LMS Schoology in improving the learning outcomes of MA English Teacher Training participants at the Religious Education and Training Center Surabaya.

The magnitude of the influence of the variable use of LMS Schoology on the increase in learning outcomes of MA English Teacher Training participants at the Religious Education and Training Center Surabaya is $77.4 \%$.

The findings of this research may supply some valuable sagacity or understanding for Widyaiswara, instructors, Education and Training policy makers in the realm of teacher training.

\section{E. REFERENCES}

Abuddin, N. 2011. Perspektif Islam Tentang Strategi Pembelajaran. Jakarta: Kencana Prenada Media Group.

Aljaser, Afaf M. 2019. "The Effectiveness of E-Learning Environment in Developing Academic Achievement and the Attitude to Learn English among Primary Students." Turkish Online Journal of Distance Education 20, no. 2: 176-94. Amiroh. 2013. "Antara Moodle, Edmodo Dan Schoology." In Amiroh.Web.Id. Anwar, P. 2008. Manajemen Sumber Daya Manusia. Bandung: PT. Remaja Rosda Karya Bandung.

Baharudin, Rahmawati. 2013. "Keefektifan Media Belajar Berbasis Teknologi 
Informasi Dan Komunikasi.” Jurnal Tadris Stain Pamekasan 5, no. 1: 111-27.

Chou, Shih- Wei, and Chien- Hung Liu. 2005. "Learning Effectiveness in a Webbased Virtual Learning Environment: A Learner Control Perspective.” Journal of Computer Assisted Learning 21, no. 1: 65-76.

Dimyati, and Mudjiono. 2006. Belajar Dan Pembelajaran. Jakarta: PT Rineke Cipta.

Fadel, H. 2016. "The Effect of Blending E-Learning Environments and Social Media on Developing the Skills of Teacher-Students in the Field of Computer Maintenance." Journal of the Faculty of Speciic Education.

Harrington, Christine, and M Aloni. 2013. "Promoting Critical Thinking through Online Discussion: Developing Questions and Managing Conversations." In Lilly Conference on College and University Teaching and Learning, Bethesda, MD.

Kadri, T. 2017. Rancangan Penelitian. Yogyakarta: Deepublish.

Mahmud, Murni. 2019. "The Use of Politeness Strategies in The Classroom Context by English University Students.” Indonesian Journal of Applied Linguistics 8, no. 3: 597. https://doi.org/10.17509/ijal.v8i3.15258.

Murni, Cahyasari Kartika. 2016. "Pengaruh E-Learning Berbasis Schoology Terhadap Peningkatan Hasil Belajar Siswa Dalam Materi Perangkat Keras Jaringan Kelas X TKJ 2 Pada SMK Negeri 3 Buduran, Sidoarjo.” IT-Edu: Jurnal Information Technology and Education 1, no. 01.

Purwaningsih, R, U Rosidin, and I Wahyudi. 2017. "Pengaruh Penggunaan ELearning Dengan Schoology Terhadap Hasil Belajar Peserta Didik.” In Media_neliti.Com. https://media.neliti.com/media/publications/118118-IDpengaruh-penggunaan-e-learing-dengan-sch.pdf.

Putri, Ni Wayan Mei Ananda, I Nyoman Jampel, and I Kadek Suartama. 2014. "Pengembangan E-Learning Berbasis Schoology Pada Mata Pelajaran IPA Kelas VIII Di SMP Negeri 1 Seririt.” Jurnal EDUTECH Undiksha 2, no. 1.

Sudjana, N. 2009. Penilaian Hasil Proses Belajar Mengajar. Bandung: PT Remaja Rosdakarya.

Wu, Pengfei, Shengquan Yu, and Dan Wang. 2018. "Using a Learner-Topic Model for Mining Learner Interests in Open Learning Environments." Journal of Educational Technology \& Society 21, no. 2: 192-204. 